\title{
IN VITRO ANTIOXIDANT AND ANTI-INFLAMMATORY ACTIVITY OF THE FLOWER EXTRACTS OF OPUNTIA STRICTA
}

\author{
PRABHAKARAN D ${ }^{1,2 *}$, RAJESHKANNA A ${ }^{1}$, SENTHAMILSELVI MM ${ }^{3}$ \\ ${ }^{1}$ Department of Chemistry, Periyar E.V.R. College (Autonomous), Trichy, Tamil Nadu, India. ${ }^{2}$ Department of Quality Assurance, Chettinad \\ Cement Corporation Ltd., Ariyalur, Tamil Nadu, India. ${ }^{3}$ Department of Principal, Kamarajar Government Arts College, Surandai, Tamil \\ Nadu, India. Email: prabhakarandhanaval@gmail.com \\ Received: 25 September 2018, Revised and Accepted: 17 November 2018
}

ABSTRACT

Objective: The objective of this study was to evaluate the antioxidant and anti-inflammatory activities of the solid powder obtained from the ethyl acetate fraction from the flower Opuntia stricta.

Methods: The flower extract was evaluated for antioxidant activity by 1,1-diphenyl-2-picrylhydrazyl (DPPH) radical scavenging assay and reducing power assay was carried out by ferric-reducing capacity (FRC) assay method. The in vitro anti-inflammatory activity was evaluated using human peripheral blood mononuclear cells (PBMCs) stimulated by lipopolysaccharide (LPS) to evaluate nitric oxide (NO) production method.

Results: The solid powder obtained from the ethyl acetate fraction from the flower O. stricta showed a good antioxidant activity in scavenging DPPH radical and FRC assay with compared standard sample. This solid powder also showed good anti-inflammatory activity in cell viability (LPS-induced PBMCs) assay and NO assay.

Conclusion: These results suggest that the solid powder obtained from the ethyl acetate fraction from the flower 0 . stricta has significant antioxidant and anti-inflammatory activities.

Keywords: Antioxidant, Peripheral blood mononuclear cells, Lipopolysaccharide, Opuntia stricta, Ferric-reducing capacity.

(C) 2019 The Authors. Published by Innovare Academic Sciences Pvt Ltd. This is an open access article under the CC BY license (http://creativecommons. org/licenses/by/4. 0/) DOI: http://dx.doi.org/10.22159/ajpcr.2019.v12i3.29930

\section{INTRODUCTION}

Numerous higher plants are real wellsprings of regular items utilized as pharmaceuticals, agrochemicals, flavor and scent fixings, sustenance added substances, and pesticides [1]. The look for new plant metabolites ought to be a need in the present and future endeavors toward manageable protection and usage of biodiversity. Restorative plants are generally utilized as option helpful apparatuses for the counteractive action of numerous ailments [2,3]. Herbal-based drugs remain an important source due to the availability, relatively cheaper cost, and no side effects when compared to modern medicine [4].

The field of free radical science is increasing more consideration nowadays. Free radicals are responsive oxygen and nitrogen species which are produced by different physiological procedures in the body. Uncontrolled era of free radicals prompts assault on layer lipids, proteins, catalysts, and DNA causing oxidative anxiety and at last cell demise. These reactive oxygen species (ROS) are dependable for some degenerative human illnesses such as diabetes mellitus, tumor, neurodegenerative scatters, Alzheimer's malady, Parkinson's ailment, atherosclerosis, maturing, and provocative diseases [5]. Assurance against free radicals can be upgraded by taking adequate measures of exogenous cell reinforcements. Cell reinforcement is a steady atom which gives an electron to a rampaging free radical and ends the chain response before essential particles are harmed. Free radical rummaging property of cancer prevention agents delays or hinders cell damage [6]. To forestall free radical harm, the body has a barrier arrangement of antioxidants. In human body, there are different chemical frameworks with the expectation of complimentary radical rummaging yet micronutrients such as Vitamin E, beta-carotene, and Vitamin C are the significant antioxidant. These must be given in consume less calories as body cannot deliver these nutrients [7]. Plants are potential wellsprings of natural antioxidants, which ensure the cells against the harming impacts of ROS. Antioxidants from plant materials diminish the activity of free radicals and shield our body from different infection $[8,9]$.

Inflammation is the central feature of many physiopathological conditions in response to tissue injury and as part of host defense against microorganisms [10]. In inflammatory processes, macrophages have a key part in providing a prompt guard against outside operators. On enactment with an inflammatory jolt, for example, lipopolysaccharide (LPS), macrophages produce pro-inflammatory go-between, including nitric oxide (NO). Therefore, the search of effective non-toxic natural compounds with antioxidant activity has been identified in recent years [11]. Plants containing polysaccharides are the most potent in curing inflammatory diseases [12].

Opuntia stricta (Haw Syn. O. Dillenii Haw) is a fence having a place with Cactaceae family. This species is adjacent to the Caribbean district, tropical and subtropical bank of eastern North America, and interfacing South America. O. stricta is a tropical-subtropical animal social events and it happens in natural locales, ruderal, scraped zones, clean, bush grounds, tundra, urban regions, overwhelm prairie and woody field, dry sclerophyll timberland and forest, unforgiving slants, and riparian conditions close watercourses. The sprouts are overall yellow in shading and are found all through India, yet most normally in South India [13,14]. Ordinary names of 0 . stricta are Erect Prickly Pear, prickly cactus pear, sweet prickly pear (English), and Nopal Estricto (Spanish). In South India are called as Nagajemudu, Nagadali (Andhra Pradesh), Nagathali, and Sappathikalli (Tamil Nadu) $[14,15]$. O. stricta organic product juice was observed to be a potential wellspring of betacyanin shades and could be utilized as a characteristic red-purple nourishment colorant. This desert plant is utilized as a part of people solution as an antidiabetic and anti-inflammatory, antihyperglycemic movement, hypotensive action, neuroprotective action, and antispermatogenic action [15-19]. It is clear that Argemone mexicana $\mathrm{L}$ is rich in biological 
activities but there are no reports so far on the subtleties of the possible role of this biological activities as antioxidants and anti-inflammatory activity of this flower.

\section{METHODS}

\section{Collection of flowers}

The new flowers of $O$. stricta were gathered from Z. Suthamalli, Ariyalur (Dt.), Tamil Nadu, India. This plant was legitimately recognized by Dr. S. John Britto, Director, The Rapinat Herbarium and Center for Molecular Systematics (Authentication No. DP005 dated: January 22, 2016). St. Joseph's College (Campus), Tiruchirappalli, Tamil Nadu, India.

\section{Extraction and fractionation}

Crisp flowers ( $3 \mathrm{~kg}$ ) of 0 . stricta were removed with $90 \%$ ethanol $(5 \times 500 \mathrm{ml})$. The consolidated alcoholic concentrate was amassed in vacuum and the aqueous concentrate was progressively fractionated with petroleum ether $\left(60-80^{\circ} \mathrm{C}\right)(6 \times 250 \mathrm{ml})$, peroxide free diethyl ether $(4 \times 250 \mathrm{ml})$, and ethyl acetate $(8 \times 250 \mathrm{ml})$. Petroleum ether division and diethyl ether division did not yield any isolable substance. Ethyl acetate fraction on focus yielded a dry powder which was broken up in dimethyl sulfoxide (DMSO) to get different fixations and was utilized for additionally examines.

\section{1,1-Diphenyl-2-picrylhydrazyl (DPPH) scavenging assay}

DPPH radical searching action of the sample was decided as indicated by the technique detailed by Blois (1958). An aliquot of $0.5 \mathrm{ml}$ of test arrangement in methanol was blended with $2.5 \mathrm{ml}$ of $0.5 \mathrm{mM}$ methanolic arrangement of DPPH. The blend was shaken energetically and hatched for $30 \mathrm{~min}$ oblivious at room temperature. The absorbance was estimated at $517 \mathrm{~nm}$ utilizing UV spectrophotometer. Ascorbic acid was utilized as a positive control. DPPH free radical rummaging capacity (\%) was ascertained by utilizing the recipe [20-22].

$$
\% \text { Inhibition }=\left[\left\{\mathrm{Abs}_{\text {control }}-\mathrm{Abs}_{\text {sample }}\right\} / \mathrm{Abs}_{\text {control }}\right] \times 100
$$

Where, Abs is the absorbance of the DPPH radical+ethanol and $\mathrm{Abs}_{\text {sample }}$ is the absorbance of DPPH radical+test separate/standard.

\section{Ferric-reducing capacity (FRC) assay}

FRC assay is like the FRAP assay with the exception of that it utilizes o-phenanthroline rather than TPTZ. Phenanthroline shapes a $\mathrm{Fe}^{\mathrm{III}}$ (Phen) $)_{3}$ complex that is diminished to an orange-red-shaded $\mathrm{Fe}^{\mathrm{II}}$ (Phen) $)_{3}$ complex. The response blend containing $1 \mathrm{ml}$ of $0.05 \%$ o-phenanthroline in methanol, $2 \mathrm{ml}$ ferric chloride $(200 \mu \mathrm{M}), 20 \mathrm{ml}$ of acetate buffer, and $2 \mathrm{ml}$ of different focuses extending from 10 to $250 \mu \mathrm{g}$ was brooded at room temperature for $10 \mathrm{~min}$ and the absorbance of the same was estimated at $510 \mathrm{~nm}$. Newly arranged FRC reagent clear perusing was taken at $510 \mathrm{~nm}$. The samples tried and compared and that of ascorbic acid (standard). All estimations were done in triplicate and the average was taken [23-25].

$$
\% \text { Reduction }=A_{510 \text { sample }} / A_{510} \text { blank reagent }
$$

\section{Isolation of human peripheral blood mononuclear cells (PBMCs)} and culture

PBMCs from sound givers were disengaged from EDTA tube blood by Ficoll-Hypaque angle centrifugation. To put it plainly, peripheral blood from the givers was weakened with sterile phosphate buffer saline and overlaid on the Ficoll-Hypaque arrangement, and centrifugation was performed at $350 \times g$ for $10 \mathrm{~min}$ at room temperature. The recuperated PBMCs were refreshed in RPMI- 1640 and brooded at $37^{\circ} \mathrm{C} 95 \% \mathrm{O}_{2}+5 \%$ $\mathrm{CO}_{2}$ for $30 \mathrm{~min}$ before playing out the investigations [26].

\section{The cell viability of PBMCs with LPS stimulation}

After the PBMC isolation and pre-incubation period, $1 \times 10^{5}$ cells $/ \mathrm{ml}$ PBMC were cultured in a 96-well polypropylene plate in serum-free RPMI-1640 medium with LPS at a final concentration of $100 \mathrm{ng} / \mathrm{ml}$ and various concentrations of the sample in DMSO. Cells in all conditions were incubated at $37^{\circ} \mathrm{C}, 95 \% \mathrm{O}_{2}+5 \% \mathrm{CO}_{2}$ for $24 \mathrm{~h}$. Supernatants were removed from the treated cells to investigate nitrous oxide (NO) scavenging activity. The viability of the cells was performed to evaluate the cytotoxicity of the sample using the 3-(4,5-dimethylthiazol-2-yl)2,5-diphenyltetrazolium bromide (MTT) assay. In the control wells, cells were incubated with DMSO vehicle and without LPS. In the positive control wells, cells were incubated with LPS and DMSO vehicle. The cell viability was determined by measuring the absorbance at $570 \mathrm{~nm}$ by a microplate reader [26].

$\%$ Cell viability $=($ OD of the sample $/ O D$ of the control $) \times 100$

\section{NO inhibition assay}

NO discharged in the supernatants was explored utilizing Griess reagent. The supernatants $(100 \mu \mathrm{l})$ were blended with $20 \mu \mathrm{l}$ of $1 \%$ sulfanilamide in $5 \%$ phosphoric acid and hatched for $10 \mathrm{~min}$ at room temperature, $20 \mu \mathrm{l}$ of $0.1 \%$ naphthyl-ethylenediamine dihydrochloride were included and brooded for $10 \mathrm{~min}$ at room temperature. After that, the absorbance of the response blend was perused at $540 \mathrm{~nm}$. Sodium nitrite was utilized for the adjustment bend [27-29]

\section{Statistical analysis}

All the data were reported as the mean \pm standard deviation (SD). All statistical analyses were performed by methods for one-way analysis of variance (ANOVA) and Student's t-test utilizing GraphPad Prism statistical software package version 7.02. The $\mathrm{IC}_{50}$ esteem was processed from nonlinear backslide examination using the GraphPad Prism programming with the condition: $\left.Y=100\left[1+10^{\left(X^{\prime \prime} \log C\right.}{ }_{50}\right)\right]$. Only a value of $\mathrm{p}<0.05$ was considered statistically significant.

\section{RESULTS AND DISCUSSION}

\section{Antioxidant activity}

DPPH assay is quick, simple, and practical strategy to quantify an antioxidant effect, which includes the utilization of the free radical [30], DPPH. DPPH is usually used to test the capacity of mixes to go about as free extreme foragers or hydrogen contributors and it depends on the capacity of DPPH to decolorize within the sight of antioxidant [31,32]. The inhibition of the DPPH radical by the solid powder obtained from the ethyl acetate fraction from the flower 0 . stricta was concentration dependent (Fig. 1). The inhibition percentage of the solid powder at different concentrations $(10,50,100,200$, and $250 \mu \mathrm{g} / \mathrm{ml})$ ranged between $55.92 \pm 0.29 \%$ and $78.48 \pm 0.22 \%$. This solid fraction was capable of reducing the DPPH radical $50 \%$ with $\mathrm{IC}_{50}$ of $<10 \mu \mathrm{g} / \mathrm{ml}$ compared to standard ascorbic acid which also has an $\mathrm{IC}_{50}<10 \mu \mathrm{g} / \mathrm{ml}$. Hence, the solid obtained from the ethyl acetate fraction from the flower O. stricta showed a very good antiradical activity in scavenging DPPH radical and showed a maximum percentage inhibition of $78.48 \pm 0.22 \%$ at $250 \mu \mathrm{g} / \mathrm{ml}$ concentration. DPPH scavenging activity of 0 . stricta is shown in Table 1 .

Values are shown as for means \pm SD of triplicate. ${ }^{*} \mathrm{p}<0.05$ compared with control (one-way ANOVA and t-test).

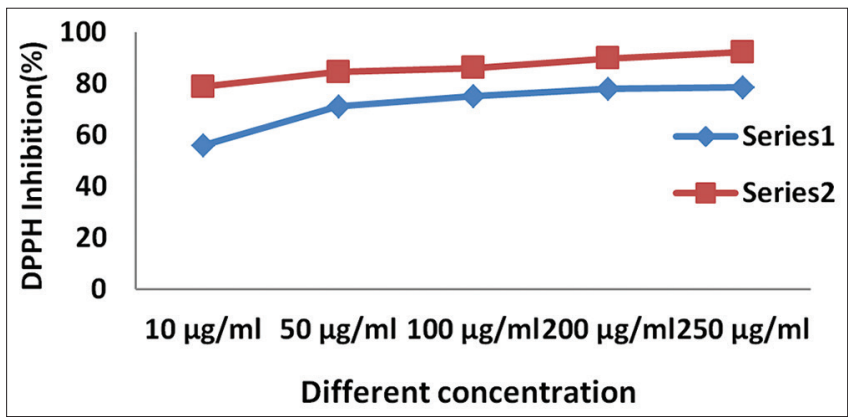

Fig. 1: 1,1-Diphenyl-2-picrylhydrazyl inhibition (\%) activity of the solid powder (Opuntia stricta flower fraction) and standard (ascorbic acid) at different concentrations 
The decreasing furthest reaches of a compound may fill in as a basic pointer of its potential antioxidant activity. The science of iron-based assays might be stuffed with the response condition:

Fe (III)-L+antioxidant $\leftrightarrow$ Fe (II)-L+oxidized antioxidant

Where, $\mathrm{L}$ is the ferrous-specific chromogenic ligand delivering the shaded species Fe(II)-L due to the concerned redox response. Longer wavelengths quite often constitute an imperative preferred standpoint in spectrophotometric strategy determination, on the grounds that most plant pigments, and additionally, a few antioxidants demonstrate huge assimilation at shorter wavelengths near UV scope of the unmistakable range. This reasoning applies for L: O-Phenanthroline instead of TPTZ ligand for modern FRAP assay. The redox response with tris(phen) $\mathrm{Fe}(\mathrm{III})$ of a polyphenolic compound $\operatorname{Ar}(\mathrm{OH}) \mathrm{n}$ is given as

$$
n \mathrm{Fe}(\text { phen })_{3}^{3+}+\mathrm{Ar}(\mathrm{OH}) n \leftrightarrow n \mathrm{Fe}(\text { phen })_{3}{ }^{2+}+\mathrm{Ar}(=\mathrm{O}) n+n \mathrm{H}^{+}
$$

The reduction values of the solid powder obtained from the ethyl acetate fraction from the flower $O$. stricta at various concentrations $(10,50,100$, 200 , and $250 \mu \mathrm{g} / \mathrm{ml}$ ) ranged between $31.36 \pm 0.80 \%$ and $93.10 \pm 1.06 \%$ are depicted in Table 2 . The $\mathrm{IC}_{50}$ values of this solid powder were found to be $23.48 \pm 1.44 \mu \mathrm{g} / \mathrm{ml}$ compared to standard ascorbic acid which has a $32.88 \pm 1.06 \mu \mathrm{g} / \mathrm{ml}$. In the concentration extend examined, all the solid powders exhibited reduced power that expanded straightly with concentration (Fig. 2). The diminishing power activity of the compound could fill in as an important pointer of the antioxidant potential. The reduction (\%) was estimated by the reductive limit of antioxidant operator and it was evaluated by the change of $\mathrm{Fe}^{3+}$ to $\mathrm{Fe}^{2+}$ oxide within sight of the sold powder. Hence, the solid powder obtained from the ethyl acetate fraction from the flower 0 . stricta showed a very good antioxidant activity in FRC assay and showed a maximum percentage reduction $93.10 \pm 1.06 \%$ at $250 \mu \mathrm{g} / \mathrm{ml}$.

\section{Anti-inflammatory activity}

The ideal condition for LPS-incited pro-inflammatory cytokines production was in PBMCs. LPS is a Gram-negative microbe which has an endotoxin and a constituent of the external layer. LPS stimulates innate immunity by regulating the production of inflammatory mediators such as tumor necrosis factor- $\alpha$ in PBMCs. The results showed (Fig. 3) that the solid powder obtained from the ethyl acetate fraction from the flower $O$.

Table 1: DPPH radical scavenging assay

\begin{tabular}{lll}
\hline Concentration $(\mu \mathrm{g} / \mathrm{ml})$ & \multicolumn{2}{l}{ \% of inhibition } \\
\cline { 2 - 3 } & Sample & Standard (ascorbic acid) \\
\hline 10 & $55.92 \pm 0.29^{*}$ & $78.98 \pm 0.43$ \\
50 & $71.10 \pm 0.27^{*}$ & $84.68 \pm 0.04$ \\
100 & $75.15 \pm 0.34^{*}$ & $86.10 \pm 0.34$ \\
200 & $77.89 \pm 0.21^{*}$ & $89.82 \pm 0.82$ \\
250 & $78.48 \pm 0.22^{*}$ & $92.15 \pm 0.50$ \\
& $\mathrm{IC}_{50}<10 \mu \mathrm{g} / \mathrm{ml}$ & $\mathrm{IC}_{50}<10 \mu \mathrm{g} / \mathrm{ml}$ \\
\hline
\end{tabular}

DPPH: 1,1Diphenyl2picrylhydrazyl

Table 2: FRC assay

\begin{tabular}{|c|c|c|}
\hline \multirow[t]{2}{*}{ Concentration $(\mu \mathrm{g} / \mathrm{ml})$} & \multicolumn{2}{|l|}{$\%$ of reduction } \\
\hline & Sample & $\begin{array}{l}\text { Standard } \\
\text { (ascorbic acid) }\end{array}$ \\
\hline 10 & $31.36 \pm 0.80^{*}$ & $25.07 \pm 0.98$ \\
\hline 50 & $66.96 \pm 1.11^{*}$ & $55.20 \pm 1.11$ \\
\hline 100 & $79.62 \pm 0.22^{*}$ & $78.00 \pm 0.48$ \\
\hline 200 & $82.06 \pm 0.42 *$ & $92.57 \pm 1.02$ \\
\hline \multirow[t]{2}{*}{250} & $93.10 \pm 1.06^{*}$ & $95.73 \pm 0.91$ \\
\hline & $\mathrm{IC}_{50}=23.48 \pm 1.44 \mu \mathrm{g} / \mathrm{ml}$ & $\mathrm{IC}_{50}=32.88 \pm 2.51 \mu \mathrm{g} / \mathrm{ml}$ \\
\hline
\end{tabular}

FRC: Ferric-reducing capacity stricta showed dose dependent. Examination of the cell viability of the fraction in PBMCs using the MTT assay had indicated that the fraction at $25-200 \mu \mathrm{g} / \mathrm{ml}$ did not affect the viability of PBMCs. Thus, the inhibition of LPS-induced mediator inflammation by the solid powder was not the result of a possible cytotoxic effect on these cells. Hence, these outcomes propose the anti-inflammatory impact of the solid powder (Table 3), focusing on pro-inflammatory cytokines generation, and using this solid powder possibly did not bring about unfavorable impacts.

Values are shown as for means \pm SD of triplicate. ${ }^{*} p<0.05$ compared with control and positive control (one-way ANOVA and t-test).

NO is a pivotal biological messenger. As an inflammatory arbiter, NO assumes a part in a wide range of physiological and pathophysiological procedures, for example, macrophage-intervened cytotoxicity, vein dilatation, smooth muscle unwinding, and neurotransmission [33]. PBMCs were refined with LPS $(100 \mathrm{ng} / \mathrm{ml})$ and the substance of the proved NO was measured in the supernatants as a component of macrophage actuation. The impact of $\mathrm{NO}$ was seen in the cell culture medium of PBMC containing diverse concentration $(25,50,100$, and $200 \mu \mathrm{g} / \mathrm{ml}$ ) of the solid powder from the ethyl acetate fraction from the flower 0 . stricta as appeared in Table 4. NO production percentage of the solid powder at different concentrations $(25-200 \mu \mathrm{g} / \mathrm{ml})$ ranged between $95.73 \pm 0.91 \%$ and $66.07 \pm 1.07 \%$ is depicted in Table 4 . This study demonstrated that the solid powder ethyl acetate fraction from the flower 0 . stricta much reduced the production of NO. The data demonstrate a significant decrease in NO production in the solid powder as compared to control group (Fig. 4).

Hence, it is clear that the solid powder obtained from the ethyl acetate fraction of 0 . stricta flowers has anti-inflammatory activity in NO assay and showed a maximum reduced NO production $66.07 \pm 1.07 \%$ at $200 \mu \mathrm{g} / \mathrm{ml}$.

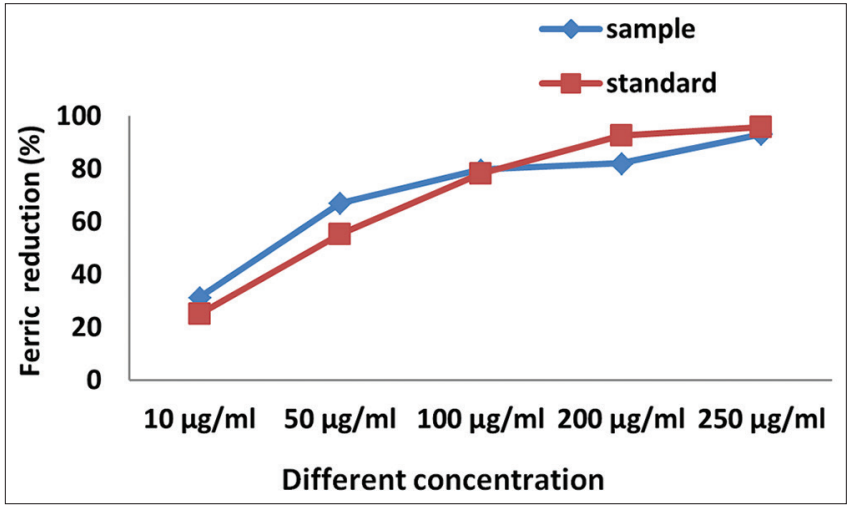

Fig. 2: Ferric reduction (\%) of the solid powder (Opuntia stricta flower fraction) and standard (ascorbic acid) at different concentrations

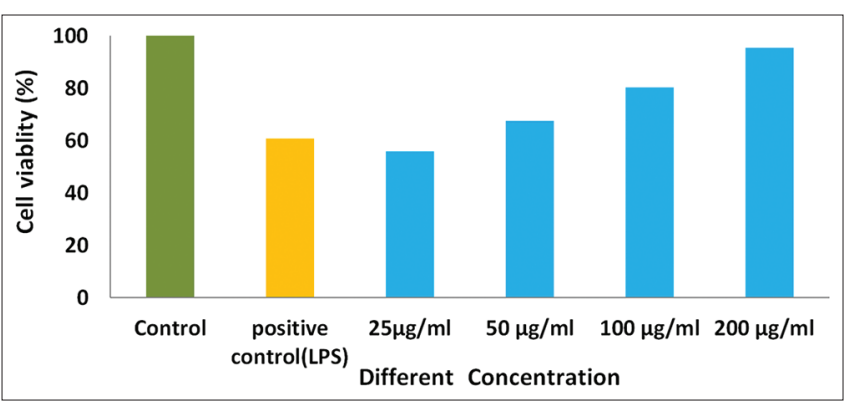

Fig. 3: The cell (peripheral blood mononuclear cells) viability percentage of without lipopolysaccharide (LPS) (control), with LPS (positive control), and the sold powder (Opuntia stricta flower fraction) at different concentrations 
Table 3: PBMCs with LPS of cell viability

\begin{tabular}{ll}
\hline Concentration $(\boldsymbol{\mu g} / \mathbf{m l})$ & Cell viability $(\%)$ \\
\hline Control & 100 \\
Positive control (LPS) & $60.79 \pm 0.74^{*}$ \\
25 & $55.91 \pm 0.87^{*}$ \\
50 & $67.49 \pm 1.14^{*}$ \\
100 & $80.23 \pm 0.62^{*}$ \\
200 & $95.37 \pm 0.87^{*}$ \\
\hline
\end{tabular}

PBMCs: Peripheral blood mononuclear cells, LPS: Lipopolysaccharide

Table 4: NO inhibition assay

\begin{tabular}{ll}
\hline Concentration $(\boldsymbol{\mu g} / \mathbf{m l})$ & NO production $(\%)$ \\
\hline Control (LPS) & 100 \\
25 & $95.73 \pm 0.91^{*}$ \\
50 & $82.89 \pm 1.04^{*}$ \\
100 & $78.87 \pm 0.30^{*}$ \\
200 & $66.07 \pm 1.07^{*}$ \\
\hline
\end{tabular}

NO: Nitric oxide, LPS: Lipopolysaccharide

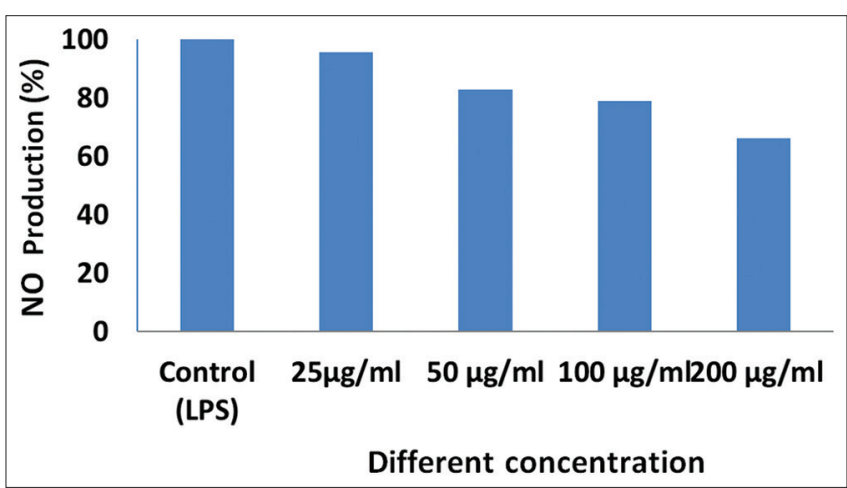

Fig. 4: The effect of solid powder (Opuntia stricta flower fraction) different concentrations on NO production by human peripheral blood mononuclear cells stimulated with lipopolysaccharide

Values are shown as for means \pm SD of triplicate. ${ }^{*} \mathrm{p}<0.05$ compared with control (one-way ANOVA and t-test)

\section{CONCLUSION}

To conclude, one might say that the present investigation had included methodical proof to the effectively accessible writing on the in vitro antioxidant and anti-inflammatory of the solid powder from the ethyl acetate fraction of the flower 0 . stricta. Moreover, work is required remembering the true objective to develop the character of the substance constituent responsible for antioxidant and antiinflammatory activities. Studies are ahead of time in our examination office to outline the subnuclear structure of the compound. This contributes toward the progression of extreme antioxidant and antiinflammatory pharmaceutical.

\section{AUTHORS' CONTRIBUTIONS}

All the authors give the same contributions to this research.

\section{CONFLICTS OF INTEREST}

The authors declare that no conflicts of interest exist among them.

\section{REFERENCES}

1. Balandrin MJ, Klocke JA. Medicinal, aromatic and industrial materials from plants: Medicinal and aromatic plant I. In: Bajaj YP, editor. Biotechnology in Agriculture and Forestry. Vol. 4. New York: Plenum Press; 1988. p. 3-36.
2. Kaur S, Mondal P. Study of total phenolic and flavonoid content, antioxidant activity and antimicrobial properties of medicinal plants. J Microbiol Exp 2014;1:1-6.

3. Rao NV. Evaluation of antioxidant potential and qualitative analysis of major polyphenols by RP-HPLC in Nymphaea nouchali Burm. Int J Pharm Pharm Sci 2010;2:98-104.

4. Narayanaswamy N, Balakrishnan KP. Evaluation of some medicinal plants for their antioxidant properties. Int J PharmTech Res 2011;3:381-5.

5. Gülçin I. Comparison of in vitro antioxidant and antiradical activities of L-tyrosine and L-Dopa. Amino Acids 2007;32:431-8.

6. Halliwell B. How to characterize an antioxidant: An update. Biochem Soc Symp 1995;61:73-101.

7. Ramassamy C. Emerging role of polyphenolic compounds in the treatment of neurodegenerative diseases: A review of their intracellular targets. Eur J Pharmacol 2006;545:51-64.

8. Jayaseelan M, Arumugam T, Thangaraj N. Evaluation of antioxidant and anti-inflammatory activities of corallocarpus epigaeus rhizomes. Int J Pharm Biomed Res 2014;5:18-24.

9. Pourmorad F, Hosseinimehr SJ. Antioxidant activity, phenol and flavonoid contents of some selected Iranian medicinal plants. Afr J Biotechnol 2006;5:66-76.

10. Brodsky M, Halpert G, Albeck M, Sredni B. The anti-inflammatory effects of the tellurium redox modulating compound, AS101, are associated with regulation of NFkappaB signaling pathway and nitric oxide induction in macrophages. J Inflamm (Lond) 2010;7:3.

11. Margret RJ, Kumaresan S, Ravikumar S. A preliminary study on the anti-inflammatory activity of methanol extract of Ulva lactuca in rat. J Environ Biol 2009;30:899-902.

12. Chandrika M, Chellaram M. Efficacy of antioxidation and anti- inflammation of the leaf extracts of Borreria hispida. Int J Pharm Pharm Sci 2016;8:369-72.

13. Merina AJ, Kesavan D, Sulochana D. Isolation and antihyperglycemic activity of flavonoid from flower petals of Opuntia stricta. Pharm Chem J 2011;45:317-21.

14. Lim TK. Edible Medicinal and Non-Medicinal Plants. Vol. 1. 2012. p. $687-92$.

15. Castellar MR, Obón JM, Alacid M, Fernández-López JA. Fermentation of Opuntia stricta (Haw.) fruits for betalains concentration. J Agric Food Chem 2008;56:4253-7.

16. Ahmed MS, El Tanbouly ND, Islam WT, Sleem AA, El Senousy AS. Antiinflammatory flavonoids from Opuntia dillenii (Ker-gawl) haw. Flowers growing in Egypt. Phytother Res 2005;19:807-9.

17. Huang X, Li Q, Li H, Guo L. Neuroprotective and antioxidative effect of cactus polysaccharides in vivo and in vitro. Cell Mol Neurobiol 2009;29:1211-21.

18. Gupta RS, Sharma R, Sharma A, Chaudhudery R, Bhatnager AK, Dobhal MP, et al. Antispermatogenic effect and chemical investigation of Opuntia dillenii. Pharm Biol 2002;40:411-5.

19. Saleem R, Ahmad M, Azmat A, Ahmad SI, Faizi Z, Abidi L, et al. Hypotensive activity, toxicology and histopathology of opuntioside-I and methanolic extract of Opuntia dillenii. Biol Pharm Bull 2005;28:1844-51.

20. Blois MS. Antioxidant determinations by the use of a stable free radical. Nature 1958;181:1199-200.

21. Adedapo AA, Jimoh FO, Koduru S, Afolayan AJ, Masika PJ. Antibacterial and antioxidant properties of the methanol extracts of the leaves and stems of Calpurnia aurea. BMC Complement Altern Med 2008;8:53

22. Sakat S, Juvekar AR, Gambhire MN. In vitro antioxidant and antiinflammatory activity of methanol extract of Oxalis corniculata Linn. Int J Pharm Pharm Sci 2010;2:146-56.

23. Benzie IF, Strain JJ. The ferric reducing ability of plasma (FRAP) as a measure of "antioxidant power": The FRAP assay. Anal Biochem 1996;239:70-6.

24. Kumar DR, Pooja M, Harika K, Haswitha E, Nagabhushanamma G, Vidyavathi N. In-vitro antioxidant activities, total phenolics and flavonoid contents of whole plant of Hemidesmus indicus Linn. Asian J Pharm Clin Res 2013;6:249-51.

25. Lim CS, Lim SL. Ferric reducing capacity versus ferric reducing antioxidant power for measuring total antioxidant capacity. Lab Med 2013;44:51-5.

26. Jenny M, Klieber M, Zaknun D, Schroecksnadel S, Kurz K, Ledochowski $\mathrm{M}$, et al. In vitro testing for anti-inflammatory properties of compounds employing peripheral blood mononuclear cells freshly isolated from healthy donors. Inflamm Res 2011;60:127-35.

27. Green LC, Wagner DA, Glogowski J, Skipper PL, Wishnok JS, Tannenbaum SR, et al. Analysis of nitrate, nitrite, and $[15 \mathrm{~N}]$ nitrate in biological fluids. Anal Biochem 1982;126:131-8. 
28. Saravanan S, Islam VI, Thirugnanasambantham K, Pazhanivel N, Raghuraman N, Paulraj MG, et al. Swertiamarin ameliorates inflammation and osteoclastogenesis intermediates in IL-1 $\beta$ induced rat fibroblast-like synoviocytes. Inflamm Res 2014;63:451-62.

29. Ignácio SR, Ferreira JL, Almeida MB, Kubelka CF. Nitric oxide production by murine peritoneal macrophages in vitro and in vivo treated with Phyllanthus tenellus extracts. J Ethnopharmacol 2001;74:181-7.

30. Richaupadhyay U, Chaurasia JK, Tiwari KN, Singh K. Antioxidant property of aerial parts and root of Phyllanthus fraternus webster, an important medicinal plant. Sci World J 2014;2014:2-5.

31. Sumanya H, Lavanya R, Reddy RU. Evaluation of in vitro anti-oxidant and anti-arthritic activity of methanolic extract of marine green algae Caulerpa racemosa. Int J Pharm Pharm Sci 2015;7:340-3.

32. Saha MR, Hasan SM, Akter R, Hossain MM, Alam MS, Alam MA, et al. In vitro free radical scavenging activity of methanol extract of the leaves of Mimuso pselengi Linn. Bangl J Vet Med 2008;6:197-202.

33. Förstermann U, Kleinert H. Nitric oxide synthase: Expression and expressional control of the three isoforms. Naunyn Schmiedebergs Arch Pharmacol 1995;352:351-64. 